\title{
Kernos
}

Revue internationale et pluridisciplinaire de religion grecque antique

4 | 1991

Varia

\section{Epigraphic Bulletin for Greek Religion}

\section{Angelos Chaniotis}

(2) OpenEdition

Journals

\section{Electronic version}

URL: http://journals.openedition.org/kernos/312

DOI: $10.4000 /$ kernos.312

ISSN: 2034-7871

\section{Publisher}

Centre international d'étude de la religion grecque antique

\section{Printed version}

Date of publication: 1 January 1991

Number of pages: 287-311

ISSN: 0776-3824

Electronic reference

Angelos Chaniotis, «Epigraphic Bulletin for Greek Religion », Kernos [Online], 4 | 1991, Online since 11 March 2011, connection on 16 September 2020. URL : http://journals.openedition.org/kernos/312 
Kernos, 4 (1991), p. 287-311.

\section{EPIGRAPHIC BULLETIN FOR GREEK RELIGION}

\section{Introduction}

The study of Greek religion is being furthered every year not only through new interpretations of old sources, but also to a great part by new archaeological, papyrological, numismatic, and epigraphic finds. This is not the place to discuss the importance of the latter source material; M.GUARDUCCI, L'epigrafia greca dalle origini al tardo impero, Roma, 1987 , p. 244-325 and 339-45 (e.g.) gives an informative picture of the various aspects of Greek religion illuminated mainly by inscriptions. However, given the present inflation of epigraphic publications it is not easy for scholars interested in the history of religion to take prompt notice of these new sources. Since the two basic media of information on new epigraphic publications, the Supplementum Epigraphicum Graecum and the Bulletin épigraphique in the Revue des Études Grecques, do not include a special section dedicated to Greek religion, it seemed appropriate to create such an Epigraphic Bulletin for Kernos. This should faciliate future work in this field, and will provide scholars, who are not necessarily specialized in Greek epigraphy, with information on recent epigraphic discoveries and publications that enrich our knowledge of religion and cults in ancient Greece.

Due to the limited space available and because almost all inscriptions have directly or indirectly to do with religion or cult, this bulletin must be very selective, restricted to texts of purely religious significance, such as : leges sacrae; dedications with explicit reference to a deity; texts related to cult associations, magic, the occult, miracles, and oracles; inscriptions mentioning deities and their epithets or new month names. Inscriptions naming eponymous or other priests and cult officials will be included in the bulletin only inasmuch as they attest the

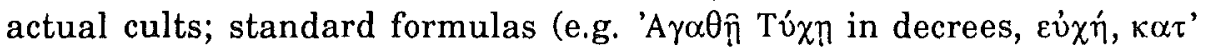
$\dot{\varepsilon} \pi \imath \alpha \gamma \dot{\eta} v$ etc. in dedications), agonistic inscriptions (unless concerning as yet unknown games or institutions), grave epigrams (if not essentially contributing to our knowledge of funerary rites or ideas abouth death), and theophoric names have to be excluded.

The present bulletin will consider articles and monographs published since 1987. Naturally, the concentration will be on the editio princeps of inscriptions. However, we shall also consider new discussions of texts edited previous to 1987 if they offer new restorations 
or interpretations. In the case of regional or subject corpora, which usually include published as well as unpublished material, only the latter can be presented in detail; other material relevant to religion will be mentioned briefly. Monographs or articles covering a topic of religious interest and using, among other sources, epigraphic evidence will not be presented at all, since these are easily accesible through the bibliography program MENTOR. Also, epigraphic publications such as Supplementum Epigraphicum Graecum, Bulletin Épigraphique, Sammelbuch griechischer Urkunden aus Ägypten, G.H.R. HORSLEY's New Documents Illustrating Early Christianity or the epigraphic corpora in the Études préliminaires aux religions orientales dans l'empire romain as well as reimpressions will not be considered here.

The lemmata will be presented in alphabetical order, since a local or thematic arrangement would only lead to unnecessary repetition. Indices of names, places, and subjects will appear periodically and will facilitate access to the desired information.

Each lemma includes bibliographical reference, concordances to parallel lemmata in Supplementum Epigraphicum Graecum and Bulletin Épigraphique, and a short resumé of only those parts of the publication, inscription, commentary or interpretation that are relevant to the study of Greek religion. Texts of inscriptions will be cited only if necessary. The editor of this bulletin will comment on the inscriptions and their interpretation only in exceptional cases; his remarks are to be found in square brackets.

Abbreviations of periodicals, academy publications etc. are those used in L'Année Philologique; the notes of transcriptions and abbreviations of epigraphic publications are those adopted by the Supplementum Epigraphicum Graecum. Names and common terms (e.g. hieromnemon, theoros, aparche etc.) will be transcribed into the Latin alphabet, without note of dialect forms or spelling variations, and will remain as close as possible to the original Greek form (e.g. Mórn $\rho$ $\Theta \varepsilon \hat{\omega} v=$ Meter Theon, 'A $\theta \alpha v \alpha i \alpha=$ Athena, Herakles and not Hercules etc.).

The editor would appreciate comments, ideas and help, and would be especially pleased to receive copies of less accessible publications. $\mathrm{He}$ would also like to express his thanks to M. Peachin for improving the English version. 


\section{Epigraphic Bulletin for Greek Religion 1987}

Some publications that were not as yet accessible to me (Horos, Studi Ellenistici II, I.STOIAN, Inscriptones Daciae et Scythiae Minoris Graecae et Latinae II) will be presented in the next issue of the bulletin.

\section{Additional Abbreviations}
Africa Romana III : $\quad$ A. MASTINo (Ed.), L'Africa Romana. Atti del III convegno di studio Sassari, 13 - 15 dicembre 1985, Sassari, 1987.

Africa Romana IV : $\quad$ A. MASTINO (Ed.), L'Africa Romana. Atti del IV convegno di studio Sassari, 12 14 dicembre 1986, Sassari, 1987.

Ametos :

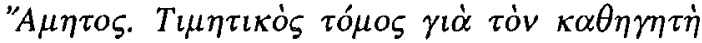

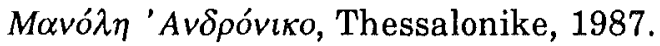

Illyrie : P. CABANES (Ed.), L'Illyrie méridionale et l'Épire dans l'antiquité. Actes du colloque international de Clermont. Ferrand 22-25 octobre 1984, ClermontFerrand, 1987.

Nicopolis : $\quad$ Proceedings of the First International Symposium on Nicopolis, 23-29 September 1984, Preveza, 1987.

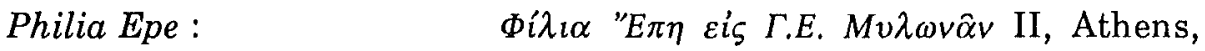
1987.

Specimina: Specimina Nova Dissertationum ex Instituto Historico Universitatis Quinqueecclesiensis de Iano Pannonio Nominatae.

Terra Antiqua Balcanica: A. FOL-V. ZHIVKOV-N. NEDJALKOV, Terra Antiqua Balcanica. Acta Centri Historiae II, Sofia, 1987.

1) W. AMELING, Eine neue Fluchinschrift des Herodes Atticus, in $Z P E$, 70 (1987), p. 159 : A. recognizes in $A D, 33$ (1978), p. 55-6 no. 1 (Athens, 2d c. AD) one of the curse texts set up by Herodes Atticus after the death of his wife and alumni, and corrects the ed. pr. The new text offers a slighlty different formula.

2) R. ARENA, Note in margine a due iscrizioni greche, in Acme, 40 (1987), p. 5-9 : Reedition of a defixio from Selinous (SEG 26, 1112, 6th c. BC) with comments on the language. 
3) R. ARENA, Di ̋̈plos epiteto divino, in PP, 42 (1987), p. 328-34 : Linguistic arguments suggest that the epitheton $\Omega$ pros, attested for Zeus in Velia, is not to be

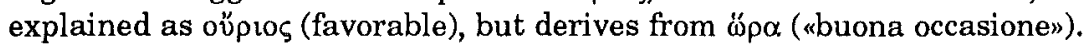

4) K. AS`AD-M. GAWLIKOWSKI, New Honorific Inscriptions in the Great Colonnade of Palmyra, in AArchSyr, 36/7 (1986/7), p. 164-71 : Ed. pr. of ten honorific inscriptions (Palmyra, $3 \mathrm{c}$. $\mathrm{AD}$ ) : a dedication to Zeus Hypsistos

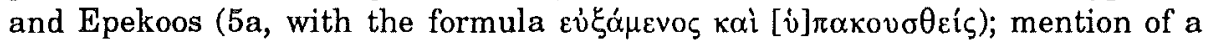
basilica of Ares patroos theos (7-8); mentions of the Macedonian months Panemos (2), Gorpiaios (3), and Daisios (6).

5) P. AUPERT, Pausanias et l'Asclépieion d'Argos, in BCH, 111 (1987), p. 511-7 : A. reads in a Hell. dedication to Isis, Sarapis and a third god, [éri zủ] -

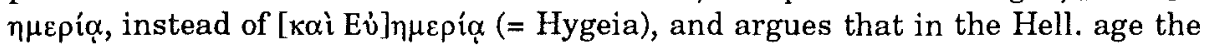
Sarapieion of Argos was also dedicated to the cult of Asklepios (p. 515 no. 7).

6) W. BLUMEL, Die Inschriften von Mylasa. Teil I : Inschriften der Stadt, IGSK, 34, Bonn, 1987 [BE 1988, 20] : The corpus includes mainly already published material : LSAM 61-66 (301-305.309); honorary decree for Zeus Osogo (306); a fragmentary lex sacra (307); a sacrificial calendar (308); funerary foundations (421-3); Dedications to : Zeus Labraundos (311-2; 311 by a chresmologos), Olympios (315, cf. 403), Osogo (316), Stratios (318.405), and Hypsistos (310); Apollon (328), Dionysos and the Demos (330), Nemesis and the Demos (337), Hermes and Herakles (332-3; 332 by a hieronikes), Herakles (334-5), Eros (331), Tyche Epiphanis (339-40, imp. times), Hera (348), and C. Marcius Censorinus (410); an altar of Zeus Labraundos (314); pillars dedicated by priests of Zeus Osogo and Zeus Zenoposeidon (319-26, early imp. times). Games for:

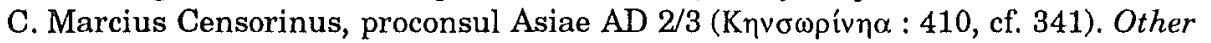
cults : Zeus [Otorkon]deon or [Ogon]deon (304=LSAM 63), Zeus Hypatos (604; cf. Hypsistos : 310), Hestia (409), the Nymphs and Apollon (723), the heroized rhetor C. Iulius Hybreas (534-556, 1st c. AD); Anubis ( ? 349). Priests of : Apollon (723), the Syrian Aphrodite (329), Aphrodite Euploia (501), Censorinus (341), Dionysos (501), Zeus Osogo and Zenoposeidon (319-27.406), Zeus Labraundos (326.501), Zeus Nemeon (501), Zeus Stratios (405), Isis (632), Meter Theon (336), Peitho (337), Poseidon Isthmios (338), Sabazios (330), Tauropolos (404.710). Priestesses of: Aphrodite Pandemos (523), Demeter (426), Isis (479), Nemesis (337). Also note a

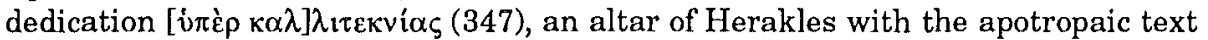

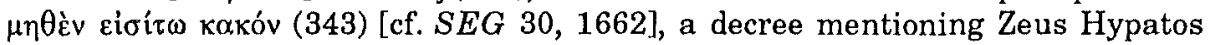
and mysteries (604, 8-9), and a decree (of Mylasa ?) mentioning the office of

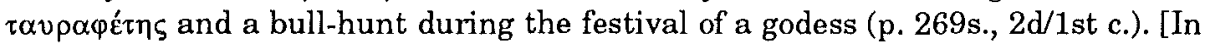

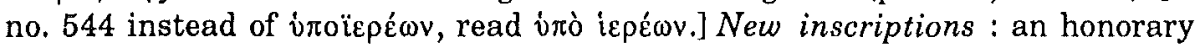

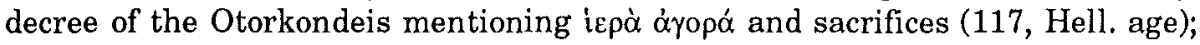
fragmentary honorary decrees nentioning a high priest of the imperial cult (143, cf. 403) and Zeus Otorkondeon (156); a dedication to Zeus Labraundos with a representation of a double axe (313, Hell. age); a small fragment of a lex sacra (?) mentioning a banquet, a sacrifice and a shrine (344); two new dedications of foreign judges in the temple of Zeus Osogo with the formula $\dot{\varepsilon} \mu v \eta \dot{ } \sigma \theta \eta$ (375-76, 1st/2d c. $\mathrm{AD}$; cf. 361-74); a small fragment of a lex sacra (?) mentioning an $\dot{\alpha} \pi \alpha \rho \chi \eta \dot{~}$ (759). 
7) K. BRAUN, Kalapodi. Bericht 1978-1982, in AA, 1987, p. 49-76 : p. 57 short presentation of graffiti on vases dedicated to Artemis with the epithets Kale and Kalliste (Kalapodi/Hyampolis) [cf. no. 35].

8) B. BRAVo, Une tablette magique d'Olbia pontique, les morts, les héros et les démons, in Poikilia : Études offertes à J.-P.Vernant, Paris, 1987, p. 185-218 [SEG 36, 855] : Reedition of a lead tablet with a defixio (3d c. BC) found at Olbia in 1908, with ample commentary. The text concerns a lawsuit and is addressed to a dead person, regarded as a chthonic daimon. B. discusses the various formulas, the character of the curse (prayer promising reward in case of success), and the magic rituals involved. After collecting the rare cases of defixiones addressed to dead persons in Hell. times (the material is vast in imp. times) as well as the curses addressed both to a chthonic diety and a dead person qualified as a daimon, B. discusses the evolution of ideas about dead persons, heros and daimons. [B. argues that Pasianax (A. Audollent, Defixionum Tabellae, p. 43s.) is not an epitheton of Pluton, but the name of the deceased to whom the curse was addressed. However, no such personal name is attested].

9) A. BRUGNONE, Epigrafia Greca, in Kokalos, 30/31 (1984/85) [1987], p. 231-55 : Review of recent epigraphical studies on Sicily; p. 232-43 are dedicated to religion. The texts reviewed include : the building inscription of the Apollonion in Syracuse (early 6th c.); a dedication to Megala (sc. thea) in Syracuse; the inscription of the temple G at Selinous; a strigil naming Soter (late 5th c.); a kantharos naming Agathos Daimon [=no. 48]; the "cosmogony" and oracular verses of Syracuse (SEG 28, 793); defixiones; missiles naming deities (Meter, Herakles, Zeus, Zeus Keraunios, Artemis, Athena, Silenos).

10) M. BUONOCORE, Musei della Biblioteca Apostolica Vaticana. Inventari e studi 2. Le iscrizioni latine e greche, Vaticano, 1987 : Reedition with brief commentary of the inscriptions in the Vatican Museums : no. 4 (IGUR 339) two pillars dedicated to Demeter, Kore, the Chthonioi Theoi with an imprecation to Enodia (ca. $A D$ 161); no. 9 (IGR I 392) a dedication to Commodus;

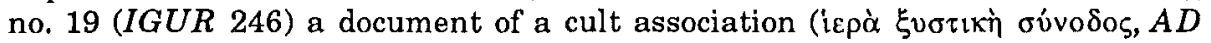
313); no. 142 (IGUR 1321) an epitaph expressing thoughts about dualism of soul and body ( immortality of the soul ( $3 \mathrm{~d} / 4$ th c.).

11) P. CABANES, L'Empereur Hadrien à Nicopolis, in Nicopolis, p. 153$167[B E 1988,787]$ : C. presents and discusses dedications to Hadrian and Sabina from Nikopolis; the emperor is identified with Zeus Dodonaios, his wife with Artemis Kelkaia.

12) A.C. CASSIO, Mıєv nella laminetta di Hipponion, in RFIC 115 (1987), p. 314-6 [BE 1988, 1033] : C. reads $\pi$ tév in the Orphic text from Hipponion (1. 12).

13) A.C. CASSIO, Addendum [to M.L. LAZZARINI, infra], in ASNP 17 (1987), p. 333-4 [BE 1988, 1033] : In 1.9 of the Orphic text from Hipponion, M.L. LAZZARINI reads OPOEENTOE (not OAOEENTOS); C. recognizes here the word

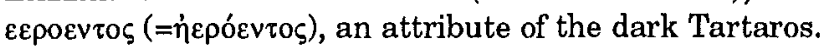


14) N. CEKA, Inscriptions bylliones, in Iliria, 1987, 2, p. 49-121 (Alb., with French summary) : Ed. pr. of inscriptions found in Byllis (3d-2d. c.) : dedications to Zeus Tropaios (4.22=SEG 35, 680), Poseidon (11-13), Parthenos (=Artemis, 14-15), Hera Teleia (16); mentions of two thiasoi in epitaphs (7.46) [cf. no. 15].

15) N. CEKA, Le koinon des Bylliones, in Illyrie, p. 135-49 [BE 1988, 803] : An inscription on a tropaion erected after a victory over Philipp V (200-198 BC) in Byllis [cf. no. 14].

16) A. CEYLAN-T. RITTI, L. Antonius Zenon, in Epigraphica, 49 (1987), p. 77-98 [BE 1988, 102] : A new inscription [=no. 66], probably from Apollonia Salbake, honoring L. Antonius Zenon Megas Aristeus, high priest of the emperor cult under Augustus (cf. MAMA VI 104). The eds. give a detailed stemma of Zenon's distinguished family and comment on the ommission of $\theta \varepsilon \dot{\alpha}$ 'Pó $\mu \eta$ in his title and on the earliest mention of the expression $\theta \varepsilon \hat{\omega} v \dot{\varepsilon} \pi \iota \varphi \alpha v \varepsilon \sigma \tau \alpha \dot{\alpha} \tau o \zeta$ for an emperor (p. 82 sq.).

17) A. CHANIOTIS, Plutarchos, praeses insularum, in $Z P E, 68$ (1987), p. 227-31 [BE 1988, 131] : Plutarch, praeses Insularum, known from a dedicatory epigram to Hera in Samos, is identified with the Plutarch, to whom Julian addressed letter no. 153 (Bidez-Cumont). He had been initiated in the mysteries of the Idean cave and probably belonged to the closest friends of the last pagan emperor.

18) M. CHRISTOL-T. DREW-BEAR, Un castellum romain près d'Apamée de Phrygie, TAM, Ergänzungsband 12, Wien, $1987:$ no. 1 is a dedication by Apollonia in Phrygia for Hadrian (134/5) to the Theoi Enorioi («dieux des frontières»).

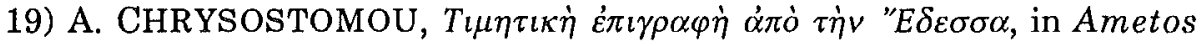
II, p. 993-1003 [SEG 36, 615; $B E 1988,836]$ : Ed. pr. of an honorary inscription from Edessa ( $2 \mathrm{~d} / 3 \mathrm{~d}$ c.) for a priestess of Dionysos (called patrios theos), high priestess of Edessa, and daughter of a high priest. It is the first epigraphic attestation for the Dionysos cult in Edessa, known otherwise from coins. Another priestess of Dionysos is known from Thessalonike.

20) P. CHUVIN, Observations sur les reliefs du théatre de Hiérapolis. Thèmes agonistiques et légendes locales, in RA, 1987, p. 97-107 [BE 1988, $229]$ : C. studies the inscriptions and reliefs found in the theater of Hierapolis (3d c. $\mathrm{AD})$ in relation to the local games and hero legends; he interprets 'Avíp as related to one of the 4 contest groups.

21) T. CoRsten, Die Inschriften von Apameia (Bithynien) und Pylai, IGSK, 32, Bonn, 1987 [BE 1988, 22] : The corpus does not include any new inscriptions relevant to religion, but the editor usually offers an ample commentary. Apameia : Dedications to غ̇ли́коo

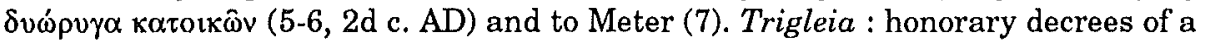
thiasos of Zeus, Kybele and Apollon; the priesthood of Zeus was reserved for males (33-35, 2d c. AD). Paladari : a dedication to Artemis Leukophryene (46, 1st/2d c.). Strobilos : a honorary inscription for a priest, gymnasiarchos and agonothetes who 
renewed a festival of Zeus Pratomysios (114, AD 178-187); a dedication to Zeus Brontaios (vegetation god) and Demeter (115); a decree of the Brontaistai (116, 2d c. AD); a dedication to Apollon (117, late 1st c. BC). Pythia Therma : dedications to Herakles (worshiped in Bithynia as Ktistes and god of the healing waters) and the Nymphs (138-140, 2d c. BC-2d c. AD).

22) M. CREMER, Das Reliefbild der Stele des Phokritos, in EA, 9 (1987), p. 115-9 : In the relief that decorates $S E G$ 36, 1158 (Strobilos, 2d c. BC) C. recognizes Eleusinian symbols (myrtle garland, capsa, band); the deceased probably officiated in the cult of Demeter, perhaps a dadouchos.

23) M. CREMER, Neue phrygische Zeus-Votive, in EA, 9 (1987), p. 120-6 : Ed. pr. of a relief dedicated to Zeus Thallos (Phrygia, unknown origin, late $3 \mathrm{~d}$ c. $\mathrm{AD})$.

24) G. DAGRON-D. FEISSEL, Inscriptions de Cilicie, Paris, 1987 [BE 1988, 25] : The new inscriptions are marked with an asterisk. Diokaisareia : a list of priests (of Zeus Olbios ?, 1st c. BC) and rhabdouchoi of a sanctuary (11*, 2d c. AD). The later list also attests for the first time the office of satabara, held for life by a woman; this office is probably of Iranian origin. Korykos : an honorific inscription for a high priest $\left(13^{*}, 2 \mathrm{~d}\right.$ c. AD); altars dedicated to Zeus Korykios Epinikios Tropaiouchos and Hermes Korykios Epinikios Tropaiouchos (16-17, imp. times). Tarsos : an altar dedicated to Apollon Epekoos (28*, 1st c. AD); a late pagan epitaph with ideas on the immortality of the soul $\left(32^{*}, 4\right.$ th c. AD). Adana : a priest of the Boule, the emperor, and the Boulaia Hestia Sebaste $\left(44^{*}, 1 \mathrm{st} / 2 \mathrm{~d} \mathrm{c}\right.$ ); a funerary imprecation to Helios $\left(48^{*}, 3 \mathrm{~d}\right.$ c. AD). Aigeai : honours for a priest of Caesar Augustus, Zeus Polieus, Athena Polias ( $74^{*}, \mathrm{AD} 39 / 40$ ); the preceding cults, attested in many Cilician cities, had probably been introduced by the Macedonians; honours for an agonothetes and priest of an emperor, whose name had been erased $\left(75^{*}\right)$

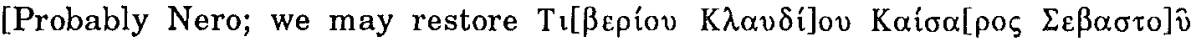
$\Gamma \varepsilon \rho \mu \alpha v[1 \kappa \circ \hat{v}]$; Nero is thus found in IGR III 345]; dedication to Dionysos Kallikarpos, Demeter Karpotrophos, Septimius Severus and Caracalla (78*, AD 209-11); the cults of Dionysos and Demeter were already attested here. Mopsos: Dedications to the Demos along with Helios (83), the Augusti (84*) and an anonymous god (85*); dedication of an altar to Thea Epekoos by a former demiourgos and priest of the emperor cult $(87,2 \mathrm{~d} \mathrm{c}$.); new edition of the epigram to Apollonios of Tyana, sent from god to appease human pain $(88,3 \mathrm{~d} / 4$ th $\mathrm{c}$.) $[=S E G$ 36, 1244]. Anazarbos : Dedications to Dea Roma and the Augusti (99), to the Nike of the gods (sc. the emperors, 111, 3d c.), and to Euthenia by a priest of Zeus Polieus and Zeus Eparchios; the last epitheton is unique; the cult of Euthenia is for the first time attested in Anazarbos (109); no. 100 mentions the oecumenical games Hadrianeia ( $2 \mathrm{~d} / 3 \mathrm{~d} \mathrm{c}$.).

25) S.I. DAKARIS, in Nicopolis, p. 1-21 [BE 1988, 791] : Ed. pr. of a dedicatory epigram to Herakles Soter in Kassope by mercenaries from Buchetion (late $2 \mathrm{~d}$ c. $\mathrm{BC})$. Oxylos is presented as the ancestor of the Buchetians.

26) J.-M. DENTZER-J. DENTZER-F. VILlENEURE, Fouilles de Si', AArchSyr, 36/7 (1986/7), p. 121-31 : P. 124 an inscription mentioning a

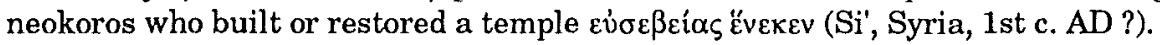


27) T. DERDA-A. LAJTAR, An Athenian dedicatory inscription to Zeus Hypsistos reconsidered, in ZPE, 70 (1987), p. 163-4 [BE 1988, 556] : New reading of a dedication to Zeus Hypsistos by a healed woman (Hesperia, 5, 1936, p. 154-6) and discussion of the healing aspects of this god, mainly worshipped by women.

28) T. DREW-BEAR, Review of : G. LAMINGER-PASCHER, Beiträge $z u$ den griechischen Inschriften Lykaoniens, Wien, 1984, in Gnomon, 59 (1987), p. 604-14 [BE 1988, 65] : D-B. recognizes in no. 1 an elegiac dedication to

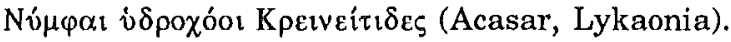

29) F. DRINI, À propos de la chronologie et des limites du koinon autonome des Prasaboi à la lumière des données des nouvelles inscriptions, in Illyrie, p. 151-8 [BE 1988, 800] : Two new manumission records from Bouthrotos (Hell.) mentioning among the eponymous officials the priests of Asklepios and Zeus Soter; the manumission took the form of a dedication to Asklepios.

30) S. DURUGÖNÜL, Athena Krisoa Oreia, in EA, 10 (1987), p. 115-6 : Ed. pr. of an Athena relief carved on a rock in Efrenköy (Kilikia) and dedicated to Athena Krisoa Oreia; MAMA III 33 is also a dedication of a grotto to the same goddess.

31) J. EBERT, Der olympische Diskus des Asklepiades und das Marmor Parium, in Tyche, 2 (1987), p. 11-15 [BE 1988, 298] : After reexamining the discus dedicated by Asklepiades ( $\mathrm{AD} 240=456$ th Olympic games), E. argues that the foundation of the Olympic games was dated officially to the year $1584 \mathrm{BC}$ (or even earlier) and this explains, why this event is not mentioned in the Parian Chronicle, which begins with the year $1581 \mathrm{BC}$.

32) N. EHRHARDT, Die politischen Beziehungen zwischen den griechischen Schwarzmeergründungen und ihren Mutterstädten. Ein Beitrag zur Bedeutung von Kolonialvehältnissen in Griechenland, in Terra Antiqua Balcanica, p. 78-117 : P. 89 E. offers a new interpretation of the

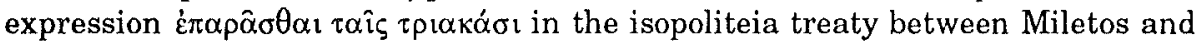
Olbia (Staatsverträge III 408, ca. 325/311); in a ceremony on the 30th day of each month, or of a certain month, the Milesians pronounced curses to preserve the wellbeing of the city; the treaty prescribes that the Olbians should participate in this ceremony. P. 116-7 discussion of the graffiti on bone tablets from Berezan (6th/5th c.; $S E G 36,694)$. E. rejects the view that these tablets pertain to the introduction of the cult of Apollon Delphinios by colonists in Olbia; they are the products, perhaps "membership tokens", of a religious sect (of Orphics ?, cf. SEG 28, 659-61). Apollon Delphinios played a central role in this sect; the number seven, which occurs in these texts, is connected to the cult of Apollon too, since his birthday was celebrated on the 7th day of each month.

33) H. ENGELMANN, Inschriften von Erythrae, in EA, 9 (1987), p. 133-52 : Ed. pr. of an archaic graffito dedication to Athena (1); a new fragment of the street list (I.Erythrae 151) mentions sanctuaries of Herakles und Kybele (4, Hell.); a dedication of strategoi to Aphrodite Strategis and the Demos (7, Hell.). 
34) R. ÉTIENNE, Les Cyclades et l'Épire : Rapports épistolaires et ambassades à l'époque hellénistique, in Illyrie, 175-7 [BE 1988, 795] : E. presents two letters of the Epirotes found in Tenos (early 2d c.), concerning the architheoros who announced the transformation of the Naia of Dodona into an agon stephanites; it is the earliest attestations of the Naia as an agon stephanites.

35) R.C.S. FELSCH-P. SIEWERT, Inschriften aus Hyampolis bei Kalapodi, in $A A, 1987$, p. 681-7 [BE 1988,670] : S. publishes two inscriptions on metal; the first registers the repayment to the sanctuary of the capital of a loan (450-425 BC), proving that the sanctuary in Kalapodi belonged to Hyampolis; the sanctuary also developed banking activities. The second inscription (mentioning the sum of 12 mnai and 13 stateres) probably indicated the content of a vessel (early 5th c.). F. reviews the other epigraphic evidence from Kalapodi : a manumission (as dedication to Artemis) and many graffiti attesting the cult of Artemis (with the epithets Kale, Kalliste, and Elaphebolos) and Apollon.

36) M. FISCHER-A. OVADIAH-I. ROLL, The Epigraphic Finds from the Roman Temple at Kadesh in the Upper Galilee, in Tel Aviv, 13/14 (1986/87), p. 60-66 [SEG 36, 1288-91] : Discussion of the four dedications (two unedited) found in the temple at Kadesh (2d-3d. c. AD) dedicated to Baalshemin

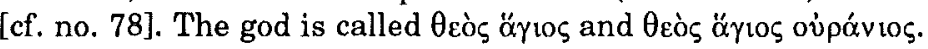

37) G. FOWDEN, Nicagoras of Athens and the Lateran Obelisk, in JHS, 107 (1987), p. 51-7 [BE 1988, 130] : F. argues that the dadouchos Nikagoras, known from two graffiti in the Syringes of the Egyptian Thebes (Syringes 1265. 1889), had been sent to Egypt by Constantine in AD 326 in order to bring the obelisk of Thutmosis III to Rome as a gift of the emperor on the occasion of his vicennalia. For this task, which expressed the emperor's desire to conciliate the pagan establishment of old Rome, Constantine chose a prominent pagan priest. Technical difficulties postponed the transport until $\mathrm{AD} 357$.

38) T. GRÜLL, Patmiaka, in Specimina, 1987, p. 15-67 : New edition, translation, and commentary of an epigram for a hydrophoros of Artemis Patmia, (KAIBEL, EG 872, 3d/4th c.) and of a dedication to the same goddess $\left(S y l l{ }^{3} 1152\right)$. G. discusses the function of the hydrophoroi in sacrifice and mysteries, and comments on the term $\pi \alpha \rho \alpha \beta \dot{\omega} \mu t \alpha$ (sacrifice beside the altar), on the sacrificial ritual, and on the legend that Patmos rose from the depths of the sea in order to receive the statue of Artemis stolen by Orestes. In an Isis-hymn (P.Oxy. 1380 IV 85-6) G. recognizes

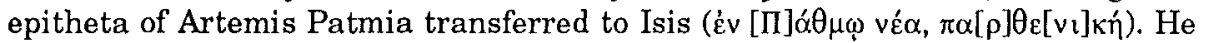
locates the Artemis sanctuary at the place of the present monastery. G. shows the major role of the Artemis cult on Patmos, its close connection to Didyma, and its sencretic character in imperial times.

39) C. HABICHT, Neue Inschriften aus Demetrias, in Demetrias V, Bonn, 1987, p. 269-306 : Ed. pr. of a late Hell. dedication by a priestess of Athena, whose cult is for the first time attested in Demetrias (5); a dedication to Zeus Meilichios (6, 2d c. BC); mention of a high priest of the emperor cult and agonothetes (9, late imp. times). New manumission records (p. 278-92, imp. times) mention the months Dios (14), Hephesteios (16), and Demetrion (18). 
40) C. HABICHT, Neue Inschriften aus Thessalien, in Demetrias V, Bonn, 1987, p. 307-17 : Ed. pr. of two dedications from Larisa, one to Artemis Lochia (5, 3d c. BC). From Pythion comes a series of dedications (Hell. and imp. times) to Asklepios (3), Apollon Lykeios (7), Apollon Pythios (8), Artemis Eileithyia (9), and Poseidon Patroos (10).

41) C. HABICHT, The role of Athens in the reorganization of the Delphic Amphictiony after 189 B.C., in Hesperia, 56 (1987), p. 59-71 [BE 1988, $662]: H$. publishes two new fragments belonging to the honorary decree for the hieromnemon [---]stratos of Phlya (IG II2 898) who was sent in $186 \mathrm{BC}$ with three other leading Athenians (probably pylagorai) to Delphi, participated in the meeting of the Amphictiony regarding the conduct of the Pythian games, contributed to the attempt of reviving the traditional council, and undertook a second trip to attend the fall meeting in Thermopylai. The new text permits us to reconsider the Athenian contribution to the reorganization of the Amphictiony.

42) H. HALFMANN, Ein neuer Statthalterkult in der Provinz Asia, in $E A, 10$ (1987), p. 83-90: Ed. pr. of an inscribed altar dedicated to Divus Augustus, Divus Iulius Caesar, Tiberius, Livia, Gaius, Lucius and Sex. Appuleius (Alexandreia Troas, ca. $\mathrm{AD}$ 14-29). H. identifies Appuleius with the consul of $29 \mathrm{BC}$ and governor of Asia, whose mother was a step-sister of Augustus, and discusses the cults of governors. This text documents for the first time the combination of a governor cult with that of the emperor's family (probably in a Kaisareion or Sebasteion). Only the cult of Divus Iulius was already attested in Alexandreia Troas.

43) G.M.A. HANFMANN, The Sacrilege Inscription : The Ethnic, Linguistic, Social, and Religious Situation at Sardis at the End of the Persian Era, in Bulletin of the Asia Institute, 1 (1987), p. 1-8 [SEG 36, 1011] : H. discusses 1 .Ephesos 2, which concerns the condemnation to death of Sardians who committed a sacrilege against Artemis Ephesia ca. 340-320 BC. [cf. no. 70.120]. H. rejects the view that the Sardians were defending their Artemis against a missionary expansion of the cult of Artemis Ephesia, since both Artemis Ephesia and Artemis of Sardis are attested in Lydian inscriptions ca. 500 BC, and the cult of Artemis of Sardis culminated in early Hell, times. Those who opposed with violence the cult of Artemis Ephesia were probably the supporters of Anahita (later Artemis Anaitis), whose cult was introduced in Sardis, together with that of Ahura-Mazda, under the Persians. An altar found in the sanctuary of Artemis of Sardis could have been dedicated to Anaitis.

44) O. HANSEN, Epigraphica Varia, in Eranos, 85 (1987), p. 99-104: 1) H. attributes SGHI 32 (465-450 BC, common decree of Halikarnassos, Salmakis, and Lygdamis) to the time after Halikarnassos' exclusion from the Dorian Amphictiony of Knidos (HDT. I 144); he regards the office of neopoios as an indication of building activity and suspects that the city foundeed its own Apollon shrine as the center of a new amphictiony under participation of Salmakis. 2) H. restors the dedication to Artemis Pergaia SEG 30, 1517 (Perge, 5th/4th c.) as follows :

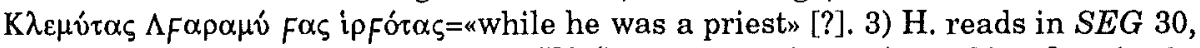

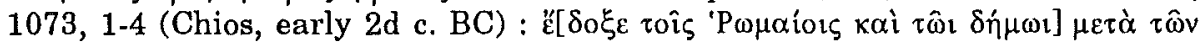

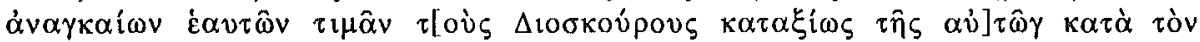

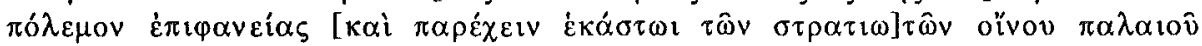


$\dot{\alpha} \mu \varphi \circ \rho \hat{\eta}$, arguing that the Dioskuroi were related to both Rome and Chios [cf. already DeRow-FORREST, in $A B S A, 77,1982$, p. 79 sq.] and that the Roman soldiers were offered old wine after their victory in Korysos (191 BC). [The restoration of the first line is absolutely impossible, the rest highly speculative].

45) M.B. HATsopoulos, Artémis Digaia Blaganitis en Macédoine, in $B C H, 111$ (1987), p. 397-412 [BE 1988, 826] : Ed. pr. of a manumission; a female slave and her son are dedicated to $\tau \hat{\alpha} \theta \varepsilon \hat{\alpha} \hat{\alpha} \tau \hat{\omega} v \beta] \alpha \tau \rho \alpha ́ \chi \omega v$, provided that her future children will be free (Blaganoi, Macedonia). The new inscription belonging to a series of dedications (cf. $B E 1977,269 ; 1984,250$; cf. SEG 27, 277) to Artemis Digaia Blaganitis offers an explanation for the epitheton Blaganitis; it derives from the place name Blaganoi=Batrachoi ( (frogs") near the river Aliakmon. H. discusses other epitheta of Artemis deriving from rivers; in an addendum he points to the dedication of bronze frogs in the shrine of Artemis Orthia in Sparta. H. rejects the explanation of Digaia as $\delta \mathbf{t}+\gamma \alpha i \alpha$ and interprets it as a dialect form of $\Delta \mathrm{tk \alpha i} \alpha$; the nearest parallels are the manumissions to Nemesis in Edessa (called Dikaia in Thessalonike) and the cult of Artemis and Dikaiosyne in Phrygia. H. also gives a long list of godesses that received manumissions through dedication in Macedonia and Phrygia; all these deities (mainly matronal forms of Artemis) are related to the

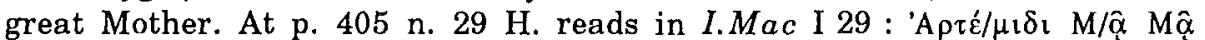

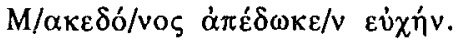

46) A. HERMARY-M. SCHMID, Rapport sur les travaux de l'École Française à Amathonte de Chypre en 1986. Le sanctuaire d'Aphrodite, in $B C H, 111$ (1987), p. 735-41 : H.-S. report (p. 736, 738 fig. 1) the discovery of a new fragment of a dedication to Sarapis and Isis on behalf of Ptolemaios VIII and the two Kleopatras ( $S E G$ 30,1573, Amathous, 142-118 BC); the new fragment also names Aphrodite who shared the same temple. An official of the Ptolemies probably tried to connect the cult of the local goddess with that of the gods of Ptolemaic Egypt.

47) G.R. HORSLEY, The inscriptions from the so-called "Library» at Cremna, in $A S, 37$ (1987), p. 49-80 [BE 1988, 240] : The inscriptions found in a bath-complex in Pisidian Kremna (m. 2d c. AD; BE 1973, 475) include dedications to Herakles (2), Nemesis (3), the Demos (4.5), Athena (7), Hygeia (8), Asklepios (9), and Apollon (10), the dedication of statues by a high priest (14), and a honorific epigram for Chrysippos, the author of philosophical works and hymns to Artemis, who had erected a shrine of Artemis (1). The texts no. 3, 4, 7, and 9 are new.

48) H.P. ISLER, Iaitas : Scavi della missione archeologica Monte Iato dell'Università di Zarigo dal 1981 al 1984, in Kokalos, 30/31 (1984/85) [1987], p. 611-20 : I. reports the find of a kantharos dedicated to Agathos Daimon (late 4th c.) found in the agora at Monte Iato (Sicily).

49) C.P. JONES, Sophron the Comoedos, in CQ, 37 (1987), p. 208-212 [BE $1988,107]$ : M. Iulius Sophron, a comic actor from Hierapolis, honoured by the synodos of victors from all the world in holy and crowned contests (T. RITTI, Hierapolis I, Roma, 1985, no. 11), can be identified with Sophron who won in the Aktia in the early $2 \mathrm{~d}$ c. AD (ARRIAN., Diss. Epict. 3, 4). J. also comments on the 
synodos of victors, which did not only include athletes, and on the manipulation of contests in Roman times.

50) D.R. JORDAN, A Greek defixio at Brussels, in Mnemosyne, 40 (1987), p. 162-6 [BE 1988, 250] : Ed. pr. of a curse tablet said to have been found in Southern Russia (4th/3d c.) and intended to influence a lawsuit. A litigant cursed the opposite party, its advocates and those who $\pi \alpha \rho \alpha \tau \eta \rho 0 \hat{\sigma} \sigma$ [probably "onlookers" who supported the opposite party]. J. adduces many parallels for defixiones in lawsuits.

51) F. JUNGE, Elephantine XI. Funde und Bauteile. 1.-7. Kampagne, 1969/1976, Mainz, 1987 [BE 1988, 989] : P. 81 no. 7.3.3.2 new edition of an altar dedicated to Chnum, Hera, Anukis, Isis, and Dionysos for Ptolemaios VIII and the two Kleopatras (after 144/3 BC).

52) V. KARAGEORGHIS, Chronique des fouilles et découvertres archéologiques à Chypre en 1986, in BCH, 111 (1987), p. 663-733 [BE 1988, 288] : P. 689 (fig. 45) mention of a Roman lamp with inscriptions mentioning Helios and Sarapis (Paphos).

53) G. KOCH, Zwei Weihreliefs aus Phrygien, in EA, 9 (1987), p. 127-31:

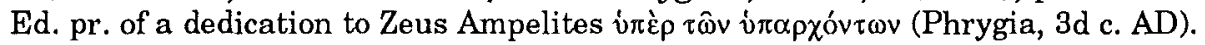

54) R. KOERNER, Eine Ehreninschrift aus Aegypten? (Inschrift F. Zucker 2), in $A F P, 33$ (1987), p. 33-5 [BE 1988, 906] : Ed. pr. of a fragmentary inscription probably found in Egypt (late 2d c. BC). Because of the

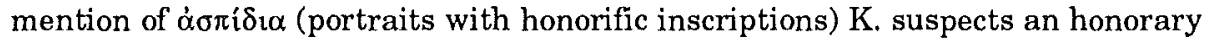
decree of an association of soldiers. [The text possibly concerns the restoration of priviliges (cf. $v o \mu_{1-}, v o ́ \mu[[\mu \alpha$ ?) or possessions of a sanctuary after some danger or

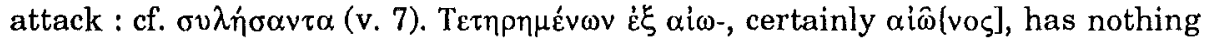
to do with soldiers of the guard, as K. suggests, but probably with privileges. A god, a temenos, an hierothytes, and a sacrifice for a king are also mentioned].

55) C. KOILAKOU, in $A D, 34 \mathrm{~B} 1$ (1979) [1987], p. 365 : Theon dedicates to Herakles and Athena ( ?) the door and the roof of a shrine (Chios, undated). K. comments on the cult of Herakles in south Chios.

56) E. KONSOLAKI, in $A D, 34$ B1 (1979) [1987], p. 111 : Ed. pr. of a fragmentary marble pedestal dedicated to Herakles (Troizen, 1st c. BC).

57) V. KONTORINI, Influence de Lindos sur le droit sacré de Cyrène : Les suppliants de Cyrène à la lumière d'une inscription inédite de Lindos, in Africa Romana IV.2, p. 574-80 [BE 1988, 1014] : K. mentions an unpublished lex sacra of Lindos (3d c.) concerning suppliants. The purification could be done in private houses or in temples; limits are set for the money demanded by the priest; citizens could purify suppliants with the participation of herolds. K. comments on the analogies to LSS 115 from Kyrene (4th c.) and suggests that the Lindian colonists of the 6th $\mathrm{c}$. influenced the law of Kyrene.

58) A. LAJTAR, An Athenian vow to Zeus Hypsistos, in $Z P E, 70$ (1987), p. 15-16 : L. restores the name of Zeus Hypsistos in M.B. COMSTOCK-C.C. VERMEULE, 
Sculpture in Stone. The Greek, Roman, and Etruscan Collections of the Museum of Fine Arts Boston, Boston, 1976, no. 235 and comments on its cult in Pnyx.

59) M.K. LANGdon, An Attic Decree Concerning Oropos, in Hesperia, 56 (1987), p. 47-58 [BE 1988, 349] : Ed. pr. of a fragmentary decree of the tribes Aigeis and Aiantis concerning a dispute about land in the area of Oropos (late 4th c. BC). The new text shows that land in Oropos was not only held by the sanctuary of Amphiaraos, but also by the Athenian tribes. L. 95-6 mention a shrine of Hermes Leukopyraios.

60) A. LARONDE, Cyrène et la Libye hellénistique. Libykai Historiai, Paris, 1987 [BE 1988, 1012] : L. reedits and studies the following documents of Kyrene : p. 52-8 a dedication of 5 strategoi to Apollon after a victory over the Nasamones and the Makai (350/325 BC); one of the dedicants is identified with an Apollon priest (ASAA, 1961/62, 292 no. 127); p. 66-9 a dedication to Apollon as dekate (Tod 127); p. 169-92 building activity in the sanctuary of Apollon and the agora, dedications to Zeus Soter and Apollon (4th/3d c.); p. 334-6 a decree mentioning the cult of Dionysos ( $S E G$ 9, 354); p. 426-7 ed. pr. of a dedication to Apollon Nymphagetas and the Nymphs (2d c.). Also note the studies on : prosopography in the time of Ptolemaios I, which pertains to persons known as priests or dedicants as well as to the building activity in the sanctuary of Apollon (p. 95-128); on the Kyrenean dedicants in Delphi (p. 147-9); on the theorodokoi of Argos and Delphi in Kyrene (p. 161-62.383).

61) A. LARONDE, Prêtres d'Apollon à Cyrène au 1er siècle ap. J.-C., in Africa Romana IV.2, p. 469-84 [BE 1988, 1015] : L. discusses a list of 21 priests of Apollon (QAL, 5, 1967, p. 57-61, 1st c. AD), and contributes to its chronology, the prosopography, and the social position of the priests.

62) M.L. LAZZARINI, Sulla laminetta di Hipponion, in ASNP, 17 (1987), 329-32 [BE 1988, 1033] : In the orphic text from Hipponion L. reads in 1.13 épéovo (not $\dot{\varepsilon} \lambda \varepsilon \circ \hat{v} \sigma \imath$ ) $\dot{v} \pi \alpha \chi \theta 0 v i \omega \imath \beta \alpha \sigma \imath \lambda \hat{\eta} \imath$; the guards report to Hades and then permit the soul of the deceased to drink water.

63) H. LIND, Sokrates am Ilissos. IG $I^{3} 1257$ und die Eingangsszene des platonischen Phaidros, in ZPE, 9 (1987), p. 15-9 [BE 1988, 84] : The idyllic picture of Ilissos in Phaidros resulted from the lex sacra $I G \mathrm{I}^{3} 257(440 / 420)$ forbiding tanning near Herakles' temenos.

64) M. LOMBARDO, Su alcuni graffiti vascolari dall'entroterra ionico, in Quaderni Ticinesi, 1 (1987), p. 87-99: A black figured attic oenochoe found in Laterza (6th/5th c.) with the graffito $\Delta \mathrm{IO}$ (p. 87 no. 1); since the vase was found in

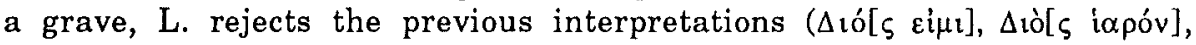
$\left.\Delta \mathrm{to}\left[v \operatorname{vo}^{\circ} \mathrm{v}\right]\right)$ and regards the graffito as an owner's inscription, a trademark or

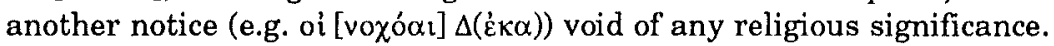

65) F.G. LO PORTO, Due iscrizioni votive archaiche dai dintorni di Tarento, in PP, 42 (1987), p. 39-50 : Ed. pr. of two dedications attesting for the first time a rural cult in the territory of Taras in archaic times. The first text (early 6th c.) refers to the dedication to Artemis of two wild goats, various cult objects (trumpet, cauldron, chest, sacrificial objects) as well as numerous farming 


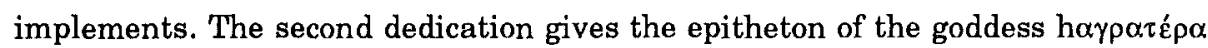
(early 5 th c.).

66) H. MALAY, An Inscription from Apollonia Salbake in Caria, in EA, 9 (1987), p. 73-5 : Ed. pr. of an honorific inscription for L. Antonius Zenon, high priest of Asia (mid 1st c. AD) [= no. 16].

67) H. MALAY, Letter of Antiochos III to Zeuxis with two covering letters (209 BC), in EA, 10 (1987), p. 7-17 : Ed. pr. of 3 letters (Mysian Pteleai, 209 BC) concerning the appointment of Nikanor as chief-priest of all the sanctuaries in the region beyond Taurus; Nikator was also in charge of the sanctuaries and administrator of their revenues, a position held by a certain Dion under Antiochos II. M. discusses the historical context, the reorganization of dynastic cult by Antiochos III, his policy of protecting the religious centers, and the office of $\dot{\varepsilon} \pi i \hat{\omega} \mathrm{V}$ iعpôv (probably responsible for collecting money for the royal treasury in times of crisis). Nikanor retained his office until at least $196 \mathrm{BC}$ (I.Amyzon 15 B); his name can be restored in I.Amyzon 14-15.

68) G. MARTORANA, Culti e miti, in Kokalos, 30/31 (1984/85) [1987], p. 299-311 : Review of recent epigraphical finds pertaining to cults and myths of Sicily. Among other texts the oracular response found in Akrai (SEG 28, 793) related to Zeus, Maia, the Nymphs, Apollon, and Artemis; the inscription of Temple $\mathrm{G}$ in Selinous; a dedication to Asklepios; attestation of Silanos (cult or personal name?).

69) O. MASSON, Notes sur les inscriptions grecques du Musée du Louvre jadis conservées au cabinet des médailles, in $B C H, 111$ (1987), p. 267-79 [SEG 36, 1251; $B E$ 1988, 29] : New edition (p. 275-7) of a dedication to Zeus Keraunios, Aphrodite, the Polis, the Demos, and the Homonoia found in Kition

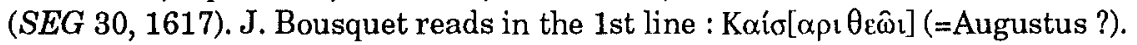

70) O. MASSON, L'inscription d'Éphèse relative aux condamnés à mort de Sardes (I.Ephesos 2), in REG, 100 (1987), p. 225-39 [SEG 36, 1011] : M. republishes (with minor restorations) and discusses I.Ephesos 2 . The text concerns the condamnation to death of 46 Sardians who commited a sacrilege against Artemis Ephesia ca. 340-320 BC. When the Ephesians sent a theoria to Sardis to bring the sacred clothes to the local Artemision founded by the Ephesians, the condemned persons mishandled the theoroi and the hiera (probably the offerings). Their motive is not known, but since the condemned persons include a priest and an hierokeryx the most probable motive was animosity against a foreign cult [cf. no. 43.120]. The condemned priest Paktyes is probably the father of Attis, the Dionysos priest known from Delphinion 135, 40.

71) O. MASSON, Vocabulaire grec et épigraphie : $\alpha \rho \alpha ́ \alpha$ «prière, ex voto», in : J.T. KILLEN-J.L. MELENA (Eds.), Studies in Mycenaean and Classical Greek Presented to J. Chadwick, Minos 20/22, Salamanca, 1987, p. 383-8 : Collection and discussion of the epigraphic evidence from Smyrna [cf. no. 85], Cyprus and Crete for the use of $\alpha \rho \alpha$ in the sense of dedication.

72) A. MASTINO, La recerca epigrafica in Africa (1973-1985), in Africa Romana III, p. 113-66 : P. 140-4 are dedicated to the epigraphic documentation 
of religious life in Africa (mostly of local cults); the epigraphic testimonies also pertain to Apollon, Asklepios, Diana Augusta, Herakles-Melqart, Kybele, Magna Mater, Mithras, the Palmyrian Gods, the Nymphs, Pluton, Poseidon, Sarapis, the emperor cult, and the priestly offices in imp. Africa.

73) V. MITSOPOULOS-LEON-F. GLASER, Lousoi 1985/86, in JÖAI, 57, $1986 / 87$, Beiblatt, p. 17-22 [SEG 36, 375] : Mention of a bronze chest dedicated to Artemis, found in the sanctuary of Artemis Hemera in Lousoi.

74) H. MÜLLER, Ein Heilungsbericht aus dem Asklepieion von Pergamon, in Chiron, 17 (1987), p. 193-233 [BE 1988, 116] : M. publishes the first known description of a cure found in the Asklepieion of Pergamon (late $2 \mathrm{~d}$ c. AD). P. Aelius Theon of Rhodos, already known as dedicant to Eurostia and member of a leading Lindian family, had been healed by Asklepios after eating every morning, for 120 days, 15 pepper corns and half an onion, and drinking no water. This recepie had been recommended by Asklepios, who probably appeared in a dream. After this therapy, Theon dedicated a statue, probably showing the god as a boy. This offering was also made for his nephew Plancianus, who, however, died in young years as $M$. concludes from an otherwise known gymnasiarchy, founded after his death. M. offers an exhaustive commentary on the prosopography, the probable illness of Theon, parallel medical and religious texts,

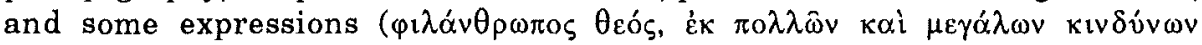
$\sigma \omega \theta \varepsilon i ́(\zeta)$.

75) V. NAJDENova, A Shrine of Ares Suregethes in Thrace, in Terra Antiqua Balcanica, p. 252-8 : Ed. pr. of a column dedicated to kyrios Ares Suregethes found in a shrine near the river Arda (Prilepsi, East Thrace, 2d/3d c.). The rarely attested local god Suregethes is identified with Ares. N. recognizes in 1.4 the epitheton Selle[--], deriving from an unattested place name [we should rather restore the name of the dedicant].

76) J. NOLLÉ, Epigraphische und numismatische Notizen, in EA 10, (1987), p. 101-6 : N. reads in a Pisidian inscription $(S E G 19,820) \tau$ òv

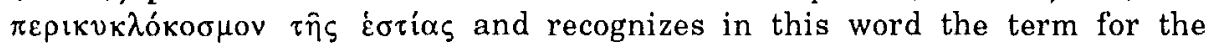
encompassing garland-frieze decoration of round altars. He also publishes a new confession text ( $\mathrm{AD} \mathrm{215/6);} \mathrm{a} \mathrm{boy} \mathrm{and} \mathrm{a} \mathrm{girl} \mathrm{have} \mathrm{been} \mathrm{punished} \mathrm{by} \mathrm{Apollon} \mathrm{Azyros}$ for stealing nets or flax. Their parents dedicated the stele with the confession of this sin after consulting the god. The theft is explicitly called an $\dot{\alpha} \mu \alpha \dot{\alpha} \rho \eta \eta \alpha \dot{\varepsilon} \pi i \tau \hat{\varphi} \theta \varepsilon \hat{\omega}$, the god being the protector of law and order. The epitheton Azyros, probably deriving from a place name, is new and can be restored in an unpublished inscription from Demirci. The shrine of Apollon Azyros can probably be located in the area of Aigaiai in Aiolis.

77) J. NOLLÉ, Pamphylische Studien 6-10, in Chiron, 17 (1987), p. 235-76 : $\mathrm{N}$. publishes an honorary decree for a high priest of the emperor cult, and an architrave fragment dedicated to $M$. Aurelius and Commodus by the high priestess and gymnasiarchos Nena, who probalby restored or built a shrine dedicated to the

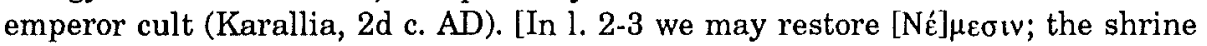
belonged also to Nemesis]. N. also reviews the cults of Karallia based on numismatic and epigraphic evidence (Athena, Selene, Demeter, Men, Aphrodite, Dionysos, Hermes, Zeus, the Samothracian gods, the emperor cult). He argues that 
the agon mentioned in TAM III.1, 164 (Termessos) is not connected with the Pamphylian Kibyra, but with Kibyra in Lykia. N. also studies the prosperity of Side in the late $3 \mathrm{~d} \mathrm{c} . \mathrm{AD}$; the numismatic and epigraphic material attests honours (metropolis, neokoria, asylia, mystis, nauarchis) and an increasing number of festivals and contests.

78) A.N. OIKONOMIDES, The inscriptions of two dedications by Epirot royalty, in Illyrie, p. 121-4 [BE 1988, 797] : O, restores BE 1949, 89 as 'Apoi⿳亠 $\Delta \mathfrak{u}$ (not $\dot{\alpha} \rho \dot{\alpha} \tau \hat{\varphi} \Delta \Delta \hat{\imath})$ and sees in Arato a Molossian queen who wanted to remind sinners of their imminent punishment [but cf. no. 71 on the meaning of $\dot{\alpha} \rho \dot{\alpha}=$ dedication»]. O. also restores $S E G 24,452$ as a dedication to Zeus Naios in Dodona after a victory of Helanos, son of Pyrrhos, over the Boiotians (273/3).

79) A. OVADIAH, The Epigraphic Finds in the Roman Temple at Kedesh in Upper Galilee, Israel, in Terra Antiqua Balcanica, p. 264 : O. mentions new Greek dedications to the sacred god of heaven found in the temple of Kadesh. They permit us to identify the god worshipped there as Baalshemin, one of the chief gods in the Syrian-Phoenician region in Roman times [cf. no. 36].

80) A. OVADIAH-I. ROLL, A Greek Dedicatory Inscription to Azeiros, in Eretz-Israel, 19 (1987), p. 270-1 (Hebr., with Engl. summary p. 80-1) : Ed. pr. of a dedication for the salvation of the emperors, to the Semitic god Azeiros, whose cult is for the first time attested in Israel (Beth-She'an=Skythopolis, $2 \mathrm{~d} / 3 \mathrm{~d} \mathrm{c}$.).

81) A. Panayotou, Un nouveau fragment de l'inscription d'Aurelius Heras (?) de Chios, in ZPE, 67 (1987), p. 183-8 [BE 1988, 551] : A new fragment of the honorific inscription for the athlete Heras (J. EBERT, Griechische Epigramme auf Sieger, Berlin, 1972, no. 79) permits a new restitution of his career. Heras won in the following games : Olympic and Isthmian games, Balbilleia in Ephesos, Panhellenia and Hadrianeia in Athens, Kapitoleia in Rome, Eusebeia in Puteoli, Sebasta in Nea Polis, Haleia in Rhodos, Olympeia in Smyrna, the provincial games of Asia and Bithynia, as well as games in Chios (late 2d c. AD).

82) A. PARIENTE, Rapport sur les travaux de l'École Française en Grèce en 1986, in $B C H, 111$ (1987), p. 591-7 [BE 1988, 589] : Brief report (p. 595-6 fig. 16) of an archaic inscription (mid 6th c.) attesting a heroon dedicated to the Seven against Thebes (cf. PAUSANIAS 2, 20, 5).

83) W. PEEK, Epigramme aus den Inschriften von Ephesos. Ergänzende Bemerkungen und Kommentare, in JÖAI, 57 (1986/87), p. 103-10 : P. restors a honorific epigram (I.Ephesos 601); it was probably dedicated by an association of Iacchos worshipers to their priest.

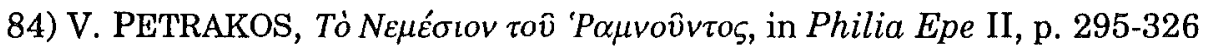
[SEG 36, 26.43.136.267; BE 1988, 138 bis] : P. discusses the history of the sanctuary of Nemesis in Rhamnus. P. 303-4 mention of an archaic account of the hieropoioi found in 1984 (6th/5th c.); p. 304 mention of a dedication to Nemesis made by soldiers from Rhamnus who participated in the expedition to Lemnos (499/8 BC); p. 305-6 ed.pr. of a dedication to Pan and the Nymphs made by three ephebes (cave of Pan in Marathon, 61/60 BC); the inscription also cites the prohibition of bringing dyed and coloured clothes into the cave. 
85) G. PETZL, Die Inschriften von Smyrna. Teil II, 1, IGSK, 24, 1, Bonn, $1987[B E 1988,18]$ : The few new texts are marked with an asterisk. Decrees : A decree related to the participation of Smyrna in the Aetolian Soteria (574, ca. 245 $\mathrm{BC}$ ), a decree of Temnos mentioning the panegyris Kynneia for Apollon Kynneios in Temnos and the festival Antiocheia in Smyrna $(584,3 \mathrm{~d}$ c.). Emperor cult : A letter of Trajan excluding a person from a leitourgia in the temple for the provincial emperor cult (593, ca. $\mathrm{AD} 101)$, a document concerning the cult personnel (neokoros, theologoi, hymnodoi) for the second neokoria of Smyrna (594, AD 124; cf. no. 697), an altar of the hymnodoi for Hadrian (595). Cult associations : A dedication to Anubis for queen Stratonike by an Anubis association (765, early $2 \mathrm{dc}$.); numerous documents pertaining to the techniton synodos and the mystai of Dionysos Breiseus and their relations to the emperors (598-601.622.639.652*.706*. 729.731-4.758-9); the association of the mystai of Demeter, called $\mu \varepsilon \gamma \alpha \dot{\alpha} \lambda \eta \theta \varepsilon \dot{\alpha} \alpha \rho \dot{\alpha}$ $\pi$ ó $\lambda \varepsilon \omega \varsigma$ $\theta \varepsilon \sigma \mu \circ \varphi \cos _{0}$ (653-5); the mystai and $\dot{\varepsilon} \mu \beta \alpha \dot{\alpha} \tau \alpha_{1}$ of Kore (726); an orphic association (738=LSAM 84); the Ga[nym]editai (probably belonging to the Dionysiac milieu, 722); an athletic association (perhaps of the hieronikai, 709). Religious offices : high priests (697), priests of Asklepios (595) and Zeus Kapetolios (774.776*), high priestesses $(640.697 .727 .772)$, a priest who honours his father (Platonic philosopher, 648), priestesses of Aphrodite Stratonikis (751), Demeter (727), Meter Theon Sipylene (641), officials (theologoi, stephanephoroi, symmartys) of the cult association of Demeter (653-5), neokoroi of Zeus (597), the Nemeseis (641.697), the emperor cult (596), a theopropos (597), the agonothetes of the games for the Nemeseis (650), officers of the provincial games in Smyrna (635), an alytarches of the Olympic games (595), an hymnodos to Dionysos Breiseus (758). Other cults : The mysteries of an anonymous god (597) and cults of Agathe Tyche (761), Aphrodite Stratonikis (723), Apollon (750-2), Apollon Kisaulodenos (754-5), Helios Apollon Kisaulodenos (753=CMRM I 28), Artemis Ephesia (724), Artemis Sebaste (=Diana Augusta, 749), Asklepios (713.750.756-7a), Asklepios Paieon (756, cf. 750), Athena (680.721.738-9), Divus Iulius (617), Herakles Epekoos (768), Herakles Kallinikos (769), Herakles Hoplophylax (770-1), Kore (746-8*), Meter Theon (744), Meter Theon Smyrnaike (743, the dedicant presents the goddess with a rabbit), the two Nemeseis (628.649.725.740-2.759), Nike (763), Sarapis (725), Theos Hypsistos (764), Tyche (697), Tyche of Marcus Aurelius (762), and Tyche of Thessalonike (760), Zeus Akraios (680), Zeus Soter (738.756). Note also inscriptions mentioning : $\tau \alpha v$ poк $\alpha \theta \alpha$ ' $\psi 1 \alpha$ (835, imp. times); the

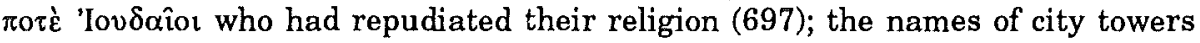
(Agathe Tyche, Eueteria, Artemis, Leto, Herakles, Dioskuroi, 613); sacred slaves (hieroi, 645.773). Other important inscriptions : An archaic dedication to Athena as $\dot{\alpha} \rho \dot{\alpha}$ (7th/6th c.); the oracle of Klaros for the refoundation of Smyrna (647, late 4th c. $\mathrm{BC}$, republished in the late $2 \mathrm{~d} \mathrm{c}$. $\mathrm{AD}$ ); a hymnus to Apollon (750); a lex sacra protecting the holy fishes of Atargatis or Artemis (735=LSAM 17); dedications to the rivers Meles, who saved the city from the plague under Marcus Aurelius (766), and Hermos (767); a letter of a Roman imperial official concerning the domains of a sanctuary (736, $\mathrm{AD} 121 / 2)$; the building of a sanctuary $(737,2 \mathrm{~d} / 3 \mathrm{~d}$ c.).

86) G. PETZL, Die Epigramme des Gregor von Nazianz über Grabräuber und das Hierothesion des Kommagenischen Königs Antiochos I, in EA, 10 (1987), p. 117-30: P. compares Gregorius' epigrams against tomb thieves and the inscription of Antiochos' hierothesion in Nemrud Dag (OGIS 383). Some of the 
epigrams referring to huge grave monuments might have been influenced by the hierothesion. It is, however, uncertain whether the monument in Nemrud Dag was plundered in Gregorius' times. The similarities between Antiochos' inscription and the poems of Gregorius do not prove a direct influence, but seem to be commonplaces of ancient rhetoric.

87) G. PETZL-H. MALAY, A new confession-inscription from the Katakekaumene, in GRBS, 28 (1987), p. 459-72: Ed. pr. and commentary of a confession-text dedicated to Mes Artemidorou Axiotenos (Kula/Lydia, 2d/3d c.). A semi-precious stone had been stolen from Syntyche; after her prayer to Mes, the stone was found burned and covered with a linen-cloth. The god appeared on the 31 st day and killed the thief, the virgin daughter of a neighbour. The mother of the girl then begged Syntyche not to declare the story, and she complied. For the failure to honor his epiphany, Mes punished Syntyche's son. [The thief did not die;

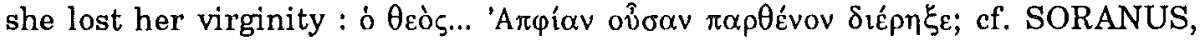
CNG IV p. 11, 29-12, 8. The treatment of the hyacinth-stone (burning, cover with linen-cloth) indicates magic].

88) M. PIÉRART-J.-P. THALMANN, Rapport sur les travaux de l'École française en Grèce en 1986. Argos 1. Agora, in BCH, 111 (1987), p. 585-91 [BE 1988,590]: Report of a 5th c. BC graffito on an Attic cup dedicated to a hero.

89) J. POUILLOUX-P. ROESCH-J. MARCILLET-JAUBERT, Salamine de Chypre XIII. Testimonia Salaminia 2. Corpus épigraphique, Paris, 1987 [BE 1988, 889] : Collection of the epigraphical testimonia for Salamis (no new texts). Among the syllabic inscriptions (with contributions by $O$. MASSON), an account pertaining to funerary rites (libations and sacrifices) for a distinguished person (2, ca. $600 \mathrm{BC}$ ), a dedication to Apollon (4,5th/4th c.) and a funerary imprecation (7). The Hell. inscriptions include : dedications to Aphrodite (41.42, cf. 246), Herakles Kallinikos (45), Zeus Olympios (46), Zeus Soterios (vases, 50.52), Sarapis, Ptolemaios III and Berenike (56), a series of dedications to Ptolemies (6173); mentions of archiereis (45.75-8.80) and archiereis of Cyprus (81.83.84); texts concerning the Cypriot association of Dionysiac artists (79.83.95, 3d-2d c.). The inscriptions of imp. times include : a text concerning the exploitation of sacred domains (of Zeus Olympios ?, 21), a letter mentioning hierodouloi of a sanctuary of Zeus Olympios $(27,2 \mathrm{~d} / 3 \mathrm{~d}$ c.), a fragmentary inventory of a sanctuary (30), an altar

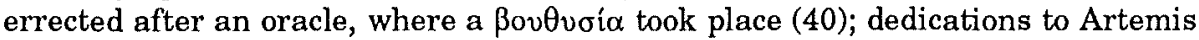
Paralia (p. 23), Dionysos (a statue of the god and the Indian panther, dedicated by an 'I $\alpha \kappa \chi \alpha \hat{i o \zeta=m y s t e s, ~ 43), ~ H e r m e s ~(44), ~ Z e u s ~ O l y m p i o s ~(47.48), ~ Z e u s ~(49), ~ I s i s ~(54), ~}$ Nemesis (55); a lamp dedicated as eixy' (51); a vase with the graffito $\theta \varepsilon 0 \hat{v}$ (53); a

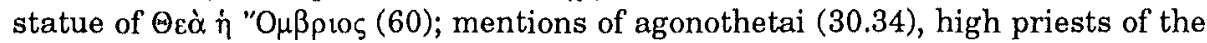
emperor cult (101.106.108.127.131.138), a high priest of Zeus Olympios and the emperors (102), a dadouchos (136); two funerary imprecations, one to Kyrios Helios (198), another with a long curse (199).

90) G. PUGliese CARRATElli, Epigrafi di Cos relativi al culto di Artemis in Cnido e in Bargulia, in PP, 42 (1987), p. 110-23 : Ed. pr. of inscriptions from Kos related to the cult of Artemis Hiakynthotrophos : 1) A decree of Knidos concerning the reorganization of the festival Hiakynthotrophia after the epiphany of the goddess, probably during the campaign of Philip V in Karia (ca. 
201 BC; P-C. suggests that the epiphany of Artemis mentioned in I.Iasos 613 should also be dated ca. 201); the festival includes sacrifices, musical and athletic games. 2) A decree of Kos declaring the participation of the city in these games; since the agon is called isopythios, Delphi had already accepted the new games. 3) A decree of Bargylia mentioning the games for Artemis Kindyas. The new epitheton probably derives from a prehellenic place name.

91) G. PUGLIESE CARRATELLI, ' $O v$ v́ $\alpha \rho[\chi]]_{\circ}$, in $P P, 42$ (1987), p. 199 [SEG $36,808]$ : P-C. recognizes, in a graffito in a cave on the Cretan mountain Ida (O. GODAR, in Festschr. Risch, p. 726 sq.), the personal name Onymarchos (1st/2d c.) known in the Gortynian elite. Onymarchos was probably a worshipper.

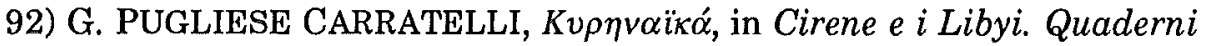
di Archeologia della Libya, 1987, p. 25-32 : P. 25-9 new reading of a list of dedicants from Kyrene (ASAA 39/40, 1961/2, no. 114); P-C. reads the name Akamantiades and recognizes a cult association of women, probably for the cult of the heros Akamas. In $S E G$ IX $72 \S 5$ he reads 'A $\alpha \mu \alpha v \tau i \omega v$ (the name of a festival) [this reading already in LSS $115 \S 4$ ], and not "ै $\alpha \alpha \mu \alpha v \tau i \omega v$.

93) G. PUGLIESE CARRATELLI, Le due dediche della stoà orientale, in Studi su Iasos di Caria. BA, Suppl. al N. 31-32, Roma, 1987, 135-6 [SEG $36,987 ; B E 1988,171]$ : Ed. pr. of three dedications to Artemis Astias, found in the Roman forum of Iasos. No. 1 is also dedicated to Hadrian (AD 135/6), no. 2 to Antoninus Pius (ca. AD 138); no. 3 possibly mentions a stephanephoros.

94) W. RADT, Pergamon. Vorbericht über die Kampagne 1986, in AA, 1987, p. 501-29 [BE 1988, 273] : Report of the find of an altar dedicated to Dionysos Kathegemon (imp. times, p. 517 fig. 16).

95) J. REYNOLDS-R. TANNENBAUM, Jews and Godfearers at Aphrodisias, Cambridge, 1987 [SEG 36, 970; BE 1988, 888] : Ed. pr. of a stele (probably a list of donors) found in the Jewish quarter of Aphrodisias ( $2 \mathrm{~d} / 3 \mathrm{~d}$ c.). R.T. offer a detailed commentary on the significance of the new find for the history of Judaism and for the society of Aphrodisias. The parallelism to contemporary Mishnaic requirements shows that this Jewish diaspora-community retained close contacts with Palestine and was more resistant to pagan syncretism than is usually thought. P. 132-140 ed. pr. of other inscriptions possibly pertaining to the Jewish community of Aphrodisias; note the dedications to Theos Epekoos (9) and Theos Hypsistos (11.12).

96) K.J. RIGSBY, $A$ decree of Haliartus on cult, in AJPh, 108 (1987), p. 729-40 [BE 1988, 393] : R. reinterprets a decree of Haliartos ( $S E G 32,456$ ) declaring its participation in a sacrifice for Athena Itonia and Zeus Keraios and in a horse-race in Ptoa. He shows that the sacrifice was to be offered in Akraiphia (not in Haliartos) and that the horse-race was held in honour of Athena Itonia (not Apollon). These ceremonies were part of the Ptoa, and were probably added to the original programm of this local festival before its reorganisation as a Boiotian festival ca. $220 \mathrm{BC}$. Haliartos did not participate regularly in the local festival, but was invited once after some unknown event (ca. 230-220). 
97) L.E. ROLLER, Hellenistic Epigraphic Texts from Gordion, in AS, 37 (1987), p. 103-33 [BE 1988, 248.293] : Ed. pr. of inscriptions from Gordion : no. 3 a votive column for Agathe Tyche, whose cult may have stemmed from the worship of Kybele (late 4th c. BC); no. 4 graffito on a kantharos mentioning Agathos Daimon (probably a convivial expression, $4 \mathrm{th} / 3 \mathrm{~d}$ c.); no. 6 statuette of Kybele dedicated to the Muses, apparently an allusion to the prominent role of music in the cult of Kybele ( $3 \mathrm{~d} / 2 \mathrm{~d} \mathrm{c}$ ); no. $7(3 \mathrm{~d} / 2 \mathrm{~d}$ c.) a postament naming Echebios, either a personal name or a divinity ("one who holds life" [attested as personal name : e.g. IG XII Suppl. 188]).

98) J. RUSSEL, The Mosaic Inscriptions of Anemurium, TAM Erg.-Bd. 13 , Wien, $1987:$ no. 2 the word Kép $\delta \omega v$ near a representation of Hermes is probably an epitheton of the god (early $3 \mathrm{~d}$ c. $\mathrm{AD}$ ); no. 7 an apotropaic text against envy ( $\varphi$ Oóvos) in an epigram for the donator of baths (5th/6th c.); discussion of the motif of envy and evil eye in building inscriptions.

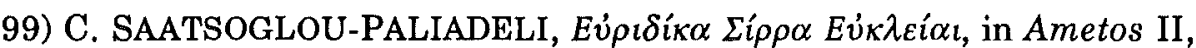
p. 733-43 [SEG 36, 651; BE 1988, 828] : Ed. pr. of a dedication to Eukleia, for the first time attested in Aigai (Vergina), by the mother of Philip II, probably after his victory in Chaironeia (337 BC).

100) M.M. SAGE, Marcus Aurelius and Zeus Kasios at Carnuntum, in AncSoc, 18 (1987), p. 151-72:S. studies the archaeological, epigraphic and philological evidence on the rain miracle during $M$. Aurelius' campaign against the Marcomanni and dates it in $\mathrm{AD} 173$ (not 172). The abbreviation JOMK in more than 30 dedications found in the religious center of Carnuntum does not refer to Jupiter Optimus Maximus Kasius (so W. Johst), but to Jupiter Karnuntinus. [Johst's interpretation seems more reasonable, since 5 texts mention the date of the miracle (III Id. Juniis), for which Zeus Kasios was responsible; Zeus Karnuntinus is otherwise not attested].

101) C. SAHIN, Zwei Inschriften aus dem südwestichen Kleinasien, in $E A, 10$ (1987), p. 1-2 : A new Hell. honorary inscription from Keramos mentioning the honor of $\pi$ po $0 v 0$ rí (cf. I.Keramos 7.9).

102) S. SAHIN, Epigraphica Asiae Minoris neglecta et iacentia, in $E A, 9$ (1987), p. 47-72:S. gives the text of inscriptions found many years ago and still remaining unpublished. Erythrai : An account of the purchase of the priestly offices of Athena S[---] and king K[---] (p. 52). Herakleia of Latmos : A letter of Zeuxis (before $192 \mathrm{BC}$ ); the city founded a monthly sacrifice on the 6th day before the end of the month for the gods, Antiochos III and his sons; in that year the god held the office of stephanephoros for the third time (p. 55-9). Klaros : an inscription

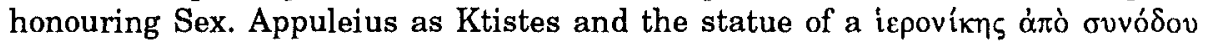
(p. 62); a series of theories of hymnodoi and $\mu^{\mu} \theta$ i Amaseia, Aphrodisias, Chios, Herakleia Salbake, Hierapytna, Laodikeia of Lykos, Phokaia, and Plotinopolis (p. 62-70, imp. times).

103) S. SAHIN, Katalog der antiken Inschriften des Museums von Iznik (Nikaia). Teil II. Testimonia, IGSK, 10, 3, Bonn, 1987 : P. 66-78 T 34 review of the agones in Nikaia (2d-3d c.) : provincial games of Bithynia, 
Kommodeia, Severeia, Augusteia, Pythia, Asklepieia, Dionysia, Valerianeia (for Valerianus and Gallienus); cf. p. 149 on the Antonieia (for Caracalla).

104) E. SCHWERTHEIM, Die Inschriften von Hadrianoi und Hadrianeia, IGSK, 33, Bonn, 1987 [BE 1988, 17] : This corpus includes mainly new texts; the few previously published inscriptions are here marked with an asterisk. Hadrianoi: A group of dedications to Zeus Kersullos or Kersussos (late 1st. c. BC-early $3 d$ c. $\mathrm{AD}: 1.2^{*} .4-8.21$ ). This new epitheton might be connected to the Thracian name Kerses or the words qers- (furrow) or karsu (field) and implies Zeus' role as a vegetation god. The dedications include the toga, gold ring, shield, and lance of a soldier (1), a relief representation of Zeus and eagles (2*), an altar (3), pillars (5.6.8). Some of the dedicants came from distant places, e.g. Aizanoi in Phrygia (4). One dedication (8) was made near a water source, probably near the pilgrims' way. Dedications to : Zeus with the unique epitheton Anabatenos that probably derives from a place name (9*, early imp. times), Zeus Ophelios (only here attested) and Dionysos $(10,2 \mathrm{~d} / 3 \mathrm{~d} \mathrm{c}$.), Zeus (11, 1st/2d c.), Dionysos (12), Eros (29, 1st c. BC), Apollon (13), Meter (18, 2d/3d c.), Xyreos or Xyras (19.20, perhaps related to the place Surius in Mysia or to Zeus Syreanos in Phrygia), and to anonymous deities (22.23.25-28.30-35.38). [27 : probably [ $\Delta \mathrm{\imath}]$ ] $\Delta \alpha \gamma \circ v \tau[\eta \vee \hat{\omega}]$; for Zeus Dagoutenos cf. WJh, 32, 1940, p. 114 sq.]. A dedicatory epigramm (36) probably for Artemis (1st c. $\mathrm{BC} / \mathrm{AD}$ ) criticizes bloody sacrifices and recommends supplicating the goddess with hymns, torches made of pine, incense and bloodless sacrifices.

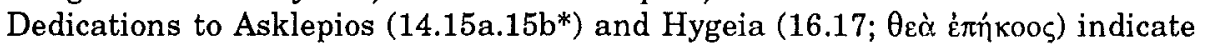
the presence of an Asklepieion in the area of Barakli=civitas Olympena (p. 16.137-8; cf. the theophoric names composed with Askl-). The dedications include snakes (14.15a.15b*); one dedicant is called Askles (14). An honorific epigram (24, 1st c.

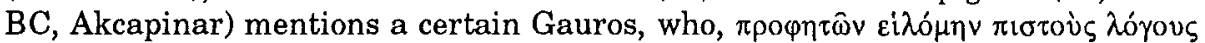

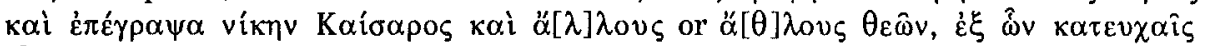
Ei̊xov $\pi \alpha \dot{v} \tau \alpha$. Gauros, probably scribe of an oracle, received the prophecies after praying; the oracles included one mentioning the victory of Ceasar in Pharsalos, or that of Octavian in Aktion. Gauros either wrote down the oracles of other gods (kai $\left.\ddot{\alpha} \lambda \lambda \circ \nu_{\varsigma} \theta \varepsilon \hat{\omega} v\right)$ or composed poems about the deeds ( $\ddot{\alpha} \theta \lambda_{0}$ ) of Herakles or Dionysos. [These verses rather describe two distinct activities : a) collection of oracles (cf. A. CHANIOTIS, Historie und Historiker in den gr. Inschriften, Stuttgart, 1988, p. 280 sq. 311); and b) prosaic or poetical works on history and mythology]. This inscription, as well as the mention of prophets in dedications to Zeus Kersoullos, Dionysos, Eros, the god Xyreos, and anonymous deiies (6.12.19.23. 25.26.29-35, late 1st c. BC-early 3d c. AD), proves the existence of an important oracle near Akcapinar (Neokesareia ?) in the territory of Hadrianoi (p. 138 sq.). Other texts mention a priest for lifetime of the $\pi \alpha \dot{\alpha} \rho$ tol $\theta \varepsilon o$ in Kaisareia $(4,2 \mathrm{~d}$ c. $\mathrm{AD})$ and a priest of Zeus Olympios, agonothetes and panegyriarches (50, 2d c. AD). Also note the epitaph of Dion, who lived honestly $\pi \alpha \rho \dot{\alpha} \tau \hat{\varphi} \theta \varepsilon \hat{\varphi}$ (Asklepios ?, no. 71, late $2 \mathrm{~d}$ c. $\mathrm{AD}$ ), and the grave epigram for Iulia Hagne of Appolonia on Rhyndakos,

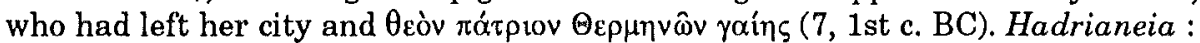
A group of inscriptions dating from the early $2 \mathrm{~d}$ to the early $3 \mathrm{~d} c . \mathrm{AD}$ is related to the cult of Zeus Pandemos (in no. 127 called Mé $\gamma \alpha \varsigma$ ) and his festival, the Pandemeia (125-8). Some of the dedicants are agonothetes of the Pandemeia (126.128*), probably founded by Hadrian (p. 158-9) and mentioned by Aelius Aristides (51, 47

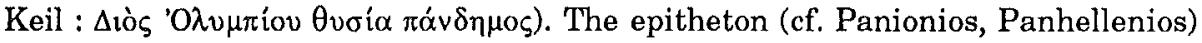


expressed the god's role in unifying the people of that area, which the Byzantine sources call Pandemon (p. 143). The god is possibly identical with Zeus Abrettenos (STRABON, 12, 8, 9). Other inscriptions are dedicated to Zeus Thimenos (new epitheton) after the victory of Septimius Severus and Caracalla over the Parthians (129, cf. p. 148; AD 201/2), to the goddess Sittene (131, 160/1 AD; only here attested, probably a form of the Great Mother), Meter Theon (130, 1/2 AD), Dionysos (133),

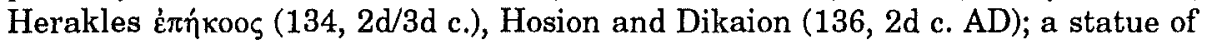
Sarapis is dedicated to the Theoi Patrooi and Marcus Aurelius (135*, AD 170). A dedicatory epigram (132, Hadrianic times) mentions an $\alpha \gamma \omega \dot{v} \alpha \rho \chi \circ \varsigma$ (the only attestation in Asia Minor, perhaps a poetic form for $\alpha$ j $\omega v 0 \theta$ é $\tau \varsigma)$, who dedicated a

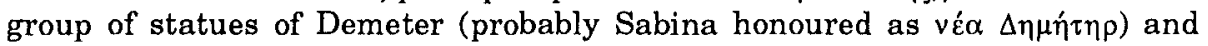
Hadrian. His family was probably related to the Bithynian dynasty and might have reserved the office of agonothetes for its members; the agones might be earlier (cf. p. 152.155). S. also studies the topography of this area and its main cult places (p. 137-54). The main cult in the Olympene was that of Zeus Olympios ( $p$. 153-4), probably identical with Zeus Pandemos and Kersoullos. Before the foundation of the cities under Hadrian, the area was probably administrated by the sanctuary and oracle of Zeus, whose prophets remained the eponymous officials. Hadrian preferred to found cities not at the site of the old cult places, but on more propitious sites. Note the unique theophoric name Eiø $\theta \varepsilon \varepsilon_{\alpha}(18)$. [Note the use of the word $\alpha \dot{\alpha} \delta \rho$ ió $\varsigma$ for statues of gods (8.11)].

105) E. SCHWERTHEIM, Ein neues hellenistisches Ehrendekret aus Adramyttion, in $E A, 9$ (1987), p. 37-44 [BE 1988, 432] : Ed. pr. of an honorary

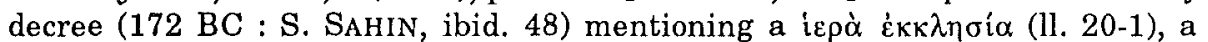
panegyris, and an agonothetes (1.27).

106) P. SIEWERT, Die neue Bürgerrechtsverleihung der Triphylier aus Mási bei Olympia, in Tyche, 2 (1987), p. 275-7: New edition and commentary of the Triphyllian decree giving civic rights to a group of persons (SEG 35, 389). The inscription attests for the first time in the Peloponnesos the month name Dios, which proves the northwestern connections of the Triphyllians. Any offense against the civic rights is regarded as sacrilege against Athena.

107) G.J.-M.J. TE RIELE, Hélisson entre en sympolitie avec Mantinée. Une nouvelle inscription d'Arcadie, in $B C H, 111$ (1987), p. 167-90 [BE $1988,621]$ : The new inscription regulates Helisson's incorporation into the state of Mantineia (early 4th c. BC). The new kome sent one representative to the council of theoroi (here administrative officials) in Mantineia and retained its religious traditions, including the right to offer sacrifices and accept religious envoys. The religious traditions were also respected in other synoikismos treaties (IG V 2,343; $S y l l^{3}$ 647).

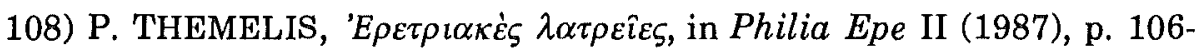
125 : Discussion of the cults of Asklepios, Eileithyia, Herakles and Apollon Prostaterios in Eretria. P. 106-9 ed.pr. of a stele dedicated to Apollon Prostaterios ( $3 \mathrm{~d}$ c. $B C)$, whose cult is for the first time attested in Euboia.

109) I. TOTH, Der Kult der kleinasiatischen Götter in Pannonien, in Specimina Nova, 1987, p. 107-29 : Collection of the epigraphic testimonia for 
the cult of Sabazios, Iuppiter Tavianus, Asklepios Soter, Artemis Ephesia, and Men in Pannonia; p. 128 ed.pr. of an altar from Budapest dedicated to Asklepios.

110) G. TOUCHAIS, Chronique de fouilles en 1986, in $B C H, 111$ (1987), p. 519-79 : P. 530 report of the inscriptions found in Argos [=nos. 82.88]; p. 554 report of a stele dedicated to Zeus and king Philip V found in a sanctuary in Maroneia (late $3 d$ c. BC).

111) Y. TSAFRIR, More Evidence for the Cult of Zeus Akraios, in EretzIsrael, 19 (1987), p. 282-3 (Hebr., with Engl. summary p. 81) : Ed. pr. of an altar dedicated to Zeus Akraios (Beth-She'an=Skythopolis, 2d c. AD).

112) K. TSANTSANOGLOU-G.M. PARAssoglou, Two Gold Lamellae from Thessaly, in Hellenika, 38 (1987), p. 3-16 : Ed. pr. and ample commentary of two gold ivy leaves found in a grave near Trikka (late 4 th c. BC), placed upon the chest of the deceased woman. The text, addressed to Persephone and expressing belief in the rebirth of the deceased as a god, has explicit Bacchic associations (ivy-leaves, mention of Bakchios=Dionysos) and differs from the texts known from other "Oprhic" lamellae. It also offers new variants of the épiposformula. T.-P. also mention another unpublished "Orphic" or "Bacchic» leaf found in Pherai.

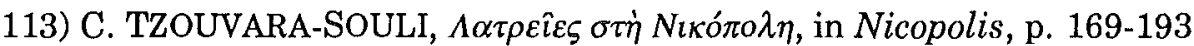
[BE 1988, 788] : Ed. pr. of an altar dedicated to Asklepios and discussion of a series of dedications (some unedited) by local communities to Augustus.

114) V. VELKOV, Ancient Epigraphy in Bulgaria 1974-1984, in Epigraphica, 49 (1987), p. 9-27 : V. reviews the contribution of epigraphy in the study of religion and cults in Bulgaria and offers a rich bibliography (p. 22-4). The studies relate to the cult of Mars and Genius in the Roman army (Novae), the cult of oriental dieties (Zeus Dolichenos, Sabazios, Hypsistos, Apollon) in the Strymon valley, the cult of Artemis in Serdica, to Mithraism, to the Thracian rider god, the local cults in Kabyle and Novae, and to religious offices.

115) F. VERKINDEREN The Honorary Decree (?) for Malousios of Gargara and the koinon of Athena Ilias, in Tyche, 2 (1987), p. 247-69 [BE $1988,419]$ : V. restudies the 6 decrees of a koinon honouring Malousios for his contributions to the sanctuary of Athena Ilias and to its panegyris (I.Ilion 3). It is not clear if this koinon was a sympolity, a league or an amphictiony. V. dates the inscriptions in $334 \mathrm{BC}$; the sanctuary might have been founded by Alexander the Great.

116) J.G. VINOGRADOV, L'inscription votive de la fille du roi Scilure à Panticapée et l'histoire de la Scythie et du Bosphore au IIe s. av. n.è., in $V D I, 1987,1$, p. 55-87 (Russ., Engl. summary) : Ed. pr. of an inscription from Pantikapaion : The daughter of the last Spartocid king dedicated an altar to a deity with the unique epitheton $\Delta i \theta \alpha \gamma o i \alpha$ (Artemis/Hekate ?) for king Pairisades V (140111).

117) J. VINOGRADOV, Der Pontos Euxeinos als politische, ökonomische und kulturelle Einheit und die Epigraphik, in Terra Antiqua Balcanica, p. 9-77 : V. discusses the cults in the Black Sea area using the 
epigraphic and numismatic material. He reiterates the view that, from archaic to late Hell. times, the Greek colonies were organized in an Amphictiony dedicated to the cult of Apollon Iatros (p. 24-5.29-30.71-72). Short discussion of the cults of Apollon Iatros and Toxophoros, the role of the oracle at Didyma during the colonization period (p. 24-5), the introduction of cults (Eleusinian dieties) and month names (Munichion) under Athenian influence in classical times (p. 40), the cult of Sarapis in Histria (p. 54), the role of the oracle of Apollon Chresterios in Kalchedon (p. 54), and the introduction of Rhodian cults (Zeus Atabirios, Athena Lindia) in late Hell. times (p. 72).

118) G. WAGNER, Les oasis d'Égypte à l'époque grecque, romaine et byzantine d'après les documents grecs, Le Caire, 1987 [BE 1988, 993-996] : W. publishes numerous graffiti and depinti (mostly unedited). Quasr el Ghoueita (p. 8-26) : the graffiti (mostly 3d-2d c.) mention Ammon (5), Amenebis (15), and Sarapis ( ?, 17); note the words $\ddot{\kappa} \kappa \omega(5.7 .10 .11 .15)$ and $\pi \rho \circ \kappa u ́ v \eta \mu \alpha(16.17)$. Chams

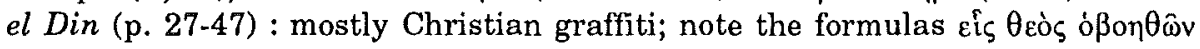

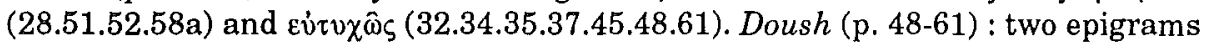
for Isis (2d c. AD); among the graffiti proskynemata of priests of Isis and Sarapis (p. 52-6, nos. 2.3.10); mentions of Herakles-Khonsoun and Psennesis or Psenpnouthes (p. 58 nos 1.2). Bagawat (p. 62-76) : the formula $\hat{\eta} \lambda \theta$ ov (p. 61 no. 5). Dakhleh (p. 77-81) : a dedication to Ammon (p. 79). P. 329-57 discussion of pagan religion in the oases of Egypt.

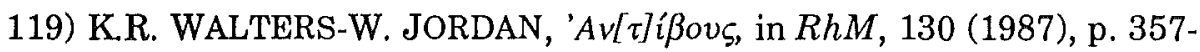
$60[B E 1988,89]$ : In the sacrificial calendar of Erchia (LSCG 43), the sheep sacrificed to Athena is called 'Avtißovs. According to M. Jameson this meant that the sheep at Erchia corresponded to the $\beta$ ov $s$ sacrificed in the city. W.J. argue that the term means the substitution of an ox through a sheep, this sacrifice being a scaled-down version of a more expensive forrunner. This term, which occurs only once in this calendar, might have been a reminder for the revisers of the older calendar, that the ox was to be substituted by a sheep. They then forgot to erase this notice.

120) H. WANKEL, $Z u$ den Chitonen für die ephesische Artemis, I.K. 11,1 $N r .2$, in $E A, 9$ (1987), p. 79-80 : W. supports the view that the theoria from Ephesos to Sardis [cf. no. 43.70] should take, and not bring, chitones for Artemis. The people of Sardis revolted against this tribute.

121) J. WIESEHÖFER, Zur Frage der Echtheit des Dareios-Briefes an Gadatas, in $R h M, 130$ (1987), p. 396-8 [SEG 36, 1042] : W. disagrees with the view of $O$. Hansen, that Dareios' letter to Gadatas related to the sanctuary of Aulai (I.Magnesia 115) is a fraud. The authenticity of the letter is supported by the similarity between the Greek text and the Achaemenid chancery praxis. The arguments of Hansen, that Xerxes destroyed the temple at Didyma and that there is a change in Achaimenid policy towards less religious tolerance, do not hold true. The original document dates from before the Ionian revolution and was written as the priests protested against Gadates' violation of the privileges of their temple.

122) D. WILLIAMS, Aegina. Aphaia-Tempel $X I$, in AA, 1987, p. 629-80 : P. 656 no. B 32 a cup dedicated to Aphaia (early 5th c. BC). 
123) F.C. WOODHUIZEN, The recently discovered Greek-Etruscan bilingue from Delphi, in Talanta, 18/19 (1986/87), p. 125-53 : Study of F.Delphes III.4, p. 199 sq. (early 5th c.). The still visible inscription of this basis is the restoration of an earlier inscription (C.Vatin); Vatin found another bilingual text on the other side of the postament. Based on the Etruscan version, W. restores the Greek text as the dedication of the Capuan clan of the Velthanes to Apollon after their victory over Kyme. W. dates the inscriptions in $484 \mathrm{BC}$, as Capua helped the exiles of Kyme to overthrow the tyranny of Aristonymos.

124) P. ZANCANI MONTUORO, Kotyle, in PP, 42 (1987), p. 300-6 : P. 300-1 brief publication of graffiti on vases dedicated as i iєpó to Aphrodite (Lokroi, early 4th c. BC) and Athena (Cosenza).

Seminar für Alte Geschichte

Angelos CHANIOTIS

Marstallhof 4

D-6900 HeIDELBERG 